\title{
地中海におけるミティゲーションの考え方と日本への道応性
}

Mitigation on Coastal Zone at French Mediterranean Sea and Applicability for Japan

小西正郎* 稲田 勉** 田中ゆう子***

Masao Konishi, Tsutomu Inada and Yuko Tanaka

\begin{abstract}
Applicability of French mitigation concept to Japanese coastal zone has been evaluated. The main concept is the method that reservation area for marine habitat would be created near development area. It could be apply to Japan because of low risk and high certainty for maintaining the performance of the coastal environments. On the other hand, it is easy to apply the enhancement methods to the ecosystem of the specific site, which are from development area within the sphere. It was considered that in the case of application to Japanese coastal zone of the concept, using the both methods is more effective. It would be necessary to establish the foundation systems to use for the habitat enhancement of reservation area.
\end{abstract}

Keywords: mitigation. Mediterranean Sea, reservation area, restoration

1.はじめに

我が国を初め諸外国においても、開発行為に先立つ環境影響評価制度の充実やミティゲーション制度の導入による 生態系保全への関心が高まっている。米国では既に、沿岸域の關発利用に対する海洋環境の保全策としてミティゲー

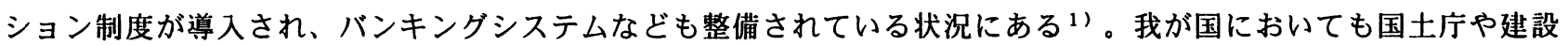
省において、ミティゲーション概念の適用可能性について調查・研究が進められてきた ${ }^{2)}$ 。またミティゲーション 的な考え方の適用により既に海域や沿岸域の整備も行われ、その睘境保全の効果も報告されている3)。一方、ミティ ゲーションの歴史の長い米国では、多くの事例やその効果も報告されているが、十分な成功を収めているとは言えな (例もある4)。このようなことから、ミティゲーションは生態系保全に大きな効果を期待できる方法であると考え られるが、制度化にあたっては、その効果の定量化、開発コストの增大、ミティゲーションサイトの確保あるいは漁 業権との関係など5) 導入に伴う社会的な影響について十分な検討が必要と考えられる。

そのため、欧米の環境保全現状やミティゲーションの制度化の実態を把握し、これらを我が国のミティゲーション の在り方に活かすことは有意義であると考える ${ }^{6)}$ 。著者らは、地中海や内海の漁業資源を利用していると言う点で 日本に類似していること及び我が国沿岸域の今後の利用形態の 1 つと考えられる海洋レジャ一の利用が多いという特 徵のあるフランス地中海治岸域を対象に、ミティゲーションの実態を調查した。その結果、フランスではミティゲー ションの法制化に至っていないが、沿岸域法等により環境破壞に対する一定の抑止が図られていること、及び事例数 は少ないが保存区域設置によるミティゲーション的施策が検討されていること等が分かった。

本稿では、その調查結果とともに地中海型のミティゲーション的施策の我が国への適応性について示す。

2. フランスにおけるミティゲーション動向.

2. 1 フランス沿岸域の現状

\section{(1) 海岸の特性}

フランスの地中海沿岸線はプロヴァンス・アルプ・コートダジュール州とラングドック・ルシオン州の 2 州に及 んでいる。コートダジュール州の海岸線は全長 $656 \mathrm{~km}$ であり、海底は遠浅ではなく、急に深くなるという特徵がある。 現在、全海岸線のうち $106.4 \mathrm{~km}$ (16.2\%) がすでに人工の海岸線になっている。水深0〜 - 20mの䇶囲は最も生物相の

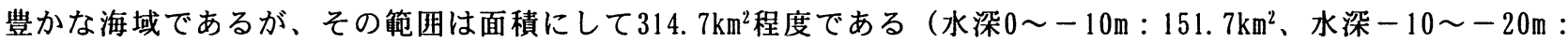
162. $9 \mathrm{~km}^{2}$ ) 。また、ラングドック州の沿岸地帯には多くの潟が点在し、タホ湖などでは牡蜈の養殖が営まれている。

（2）治岸域における開発と規制の現状

沿岸域開発の特徴は観光が主目的であるという点であり、観光の名のもとにマリーナ用の防波堤が次々建設され

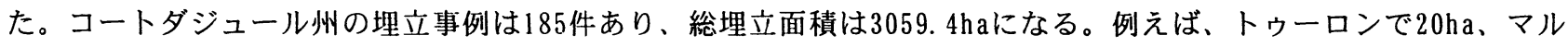
セイユで $50 \mathrm{ha} 、$ 、ニス空港では $300 \mathrm{ha}$ の水面が埋立てられた。これらの埋立地における環境破壊率は 60 〜 $65 \%$ と高く、 自然回復が難しい状況にある。開発地周辺に生息する生物を他の水域に移し、生息域を保全する措置もとられている が、生息に適した水深が限られるなどの制約があるため改善効果は顕著でない。また、ラングドック州でも観光化と

\footnotetext{
*. 正会員 㑶奥村組 技術研究所(テ300-2612 茨城県つくば市大字大砂387)

** 正会員 東洋建設(株) 土木本部調査開発室

*** 正会員 (株)東亚建設工業 土木本部技術開発部 
ともに貴重な潟の自然の消失などの影響が生じている。このようなことから、沿岸域法によって沿岸線から $100 \mathrm{~m}$ 内の 陸域における開発行為の禁止、沿岸域保存機関による土地買収制度等の環境保全措置がとられている。

\section{2 フランスにおけるミティゲーションの取組みの現状と方向}

欧州におけるミティゲーションへの取り組みは各国各様 であり法制化が図られているドイツのような例もあるが7)、 フランスでは法制化に至っていない。むしろ、開発効果と 環境影響の均衡点を探りつつ、開発受益を重視してきたケー スが多い。しかし、沿岸域法や「現状の微妙な自然バラン スを崩さない」と言った場合にも適用さる景観法が法制化 されている。これらの法律は間接的にではあるが睘境保全 に対し一定の効果を果たしている。このような状況の中で 興味深いのは、ニース大学のメネーズらが進めているミティ ゲーション的施策（以降、地中海型ミティゲーションと呼 称する) である。

地中海型ミティゲーションでは、図-1に示すように、「回 避」「最小化」「修復」と、これらを組み合わせた 4 つの 対応が用意されている。

aは、開発行為に「生物への大きな影響」「沿岸域法上の 問題」「住民の大反対」などがある場合「開発行為を中止 （回避）」するというものである。b〜dは、開発行為を実 行する際に環境へのダメージを軽減する対策であり、bは開 発時に何らかの対策すなわち「修復」を行うというもの、c は開発行為による影響を「最小化」するもの、そしてdは影 響の「最小化」と「修復」を両方行う考え方である。bより もc、cよりもdの方が環境保全の効果が高い。

メネーズらは、開発によってインパクトを受ける生物睘 境を「完全に補うこと（代償）」は困難であり、むしろ「別 のもので補う(修復)」方法が適切であるとしている。「修 復」の具体的方法としては「海草移植等の生態系の移設」 「生態系の保全（エコシステムの維持）」「開発地付近に 保存地域（全く開発できない区域）を設ける」ことを提案 している。

図ー 2 及び図ー 3 に、それぞれミティゲーションフロー 及び修復方法に応じたリスクを示す。このように 3 つの方 法はそれぞれリスクが異なり、最も将来性があり、持続可 能な方法は「保存区域設置」であるとしている。この方法 は、開発地に対して同じ面積の保存区域を要求するもので なく、面積は修復の要件にはならないと考えている。例え ば、国に返却された港を国が一般に貸し出し、収入の一部 は修復に、一部は生態系の保存などに役立てる力法である。

\section{3 地中海型ミティゲーションにおける保存区域設置 の現状}

開発に伴う地中海型ミティゲーションの事例として、Golf -Juan 港建設にともなう生息生物の移設やニースでの50 100ha の保存区域の設置が検討されているが、その事例数 は多くない。

一方、図ー4に示すようにフランス及びモナコの地中海沿岸域には、自然や生態系の保全を目的として幾つかの 保存区域が設けられている ${ }^{81}$ 。これらの設置場所は国立公園内や地方公園内であったり様々である。また、実施方 法も投錨を禁止する区域設置から人工漁礁の設置など個々に異なっている。フランスの国立公園は、沿岸域や内陸部
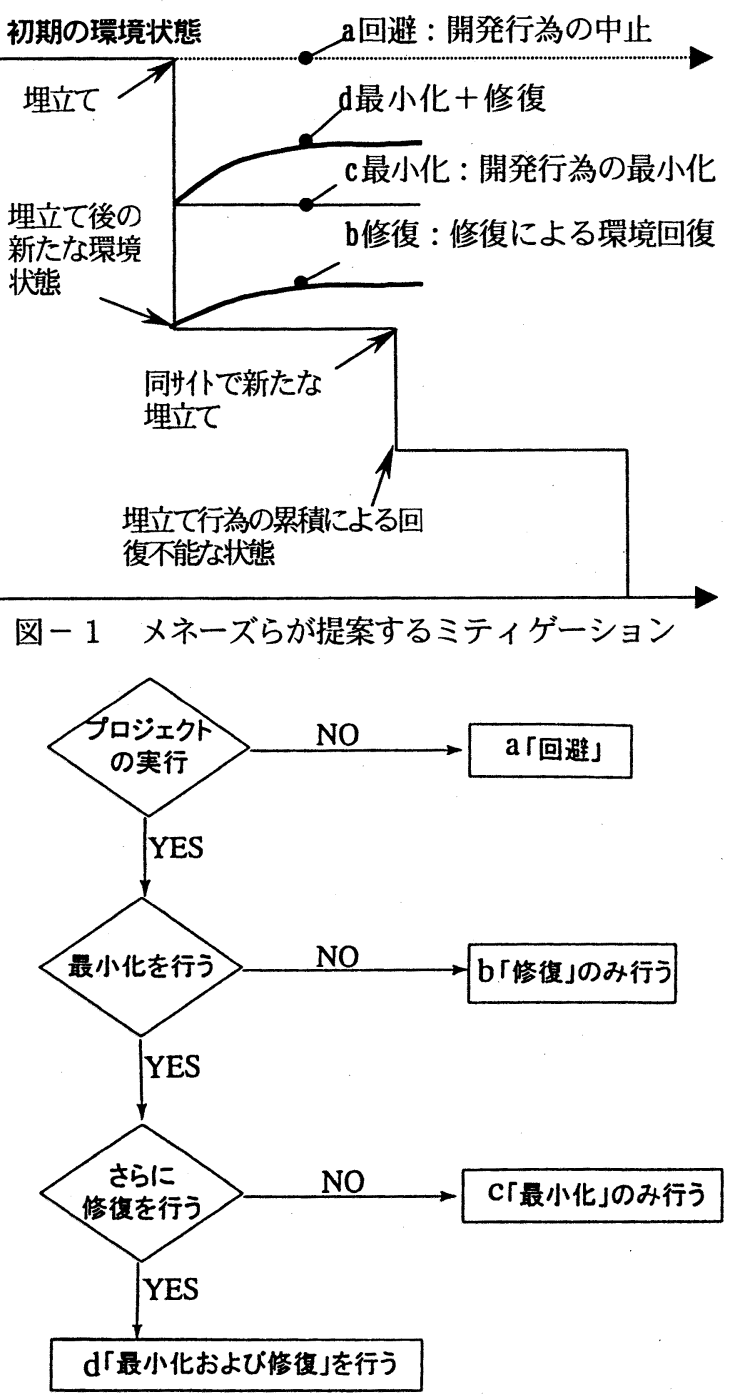

図ー2 ミティゲーションフロー

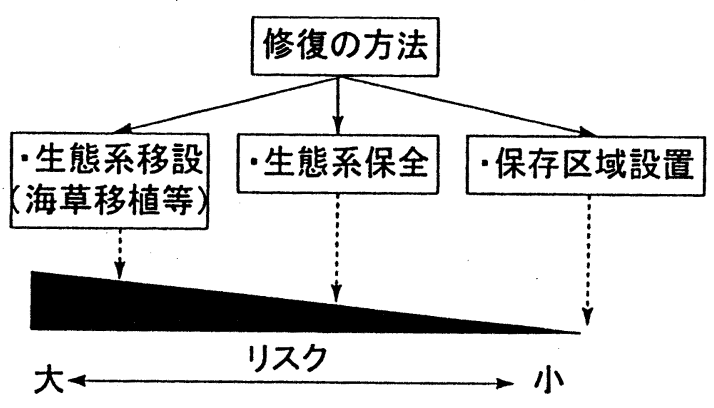

図ー $3 \quad 3$ つ修復方法に応じたリスク
図ー1 メネーズらが提案するミティゲーション 
の自然保護を目的とし、開発行為の及ばない生態環境保全地域としての役割が大きく、地中海治岸域の唯一の国立公 園であるポールクロー国立公園でもゾーニング等による貴重種の保全が図られている。ポールクロー国立公園は、周 辺海域を含めて4004haと大きな面積を有しており、自然の観光資源化による貴重な環境の理解促進などの睘境教育も 実施されている。ポールクロー国立公園における保存区域の設定規準や開発に対する考え方を次に示す。

\section{（1）ポールクロー国立公園の概要}

ポールクロー国立公園は、プロヴァンス・コート・ダジュール州の最南端にあたるイエール群島を中心に設定され た区域であり、ポールクロー(Port-Cros)島及びポルクロール(Porquerolles)島と、本土のラーティア岬 (Cap Ladier) の 3 地域から成る。ポールクロー島は公園の中心ゾーンであり、その他の地域は周辺ソーンという位置付けである。 この地方は、北緯42～44度と日本の札幌とほほ同じ緯度に位置している。しかし、北大西洋暖流からの偏西風により 冬も暖かく（ニースの $1 \sim 3$ 月の平均気温 $11.5^{\circ} \mathrm{C}$; 同じく東京 $\left.6.4^{\circ} \mathrm{C}\right)$ ）年間を通して雨が少なく日照時間も非常に長 い（年間2900時間、我が国の多いところでも2100時間）という恵まれた気象条件下にあり、地中海植物のほとんどが 生育している。公園内には、地中海の植物の保全を目的とした植物園やビジターセンターとともにキャンプ場や観光 客の宿泊施設も設けられている。ポールクロー国立公園の自然保護区分と概要を、それぞれ図ー 5 及び表一 2 に示す。 (1)国立公園の果たす役割 (Missions)

ポールクロー国立公園を含め全ての国立公園内は、自然保護とともに観光資源としての利用も同時に図られており、 再生不可能な自然の貴重性を值接理解してもらうための場としても機能している。また、課外授業をはじめとする環 境教育も実施されている。これら国立公園の役割は以下の 4 つに要約される。

・自然の保变

法律 (自然保護施行令 : 1963/12/14睘境省規則に定められている)を背景として、公園内の動植物の保護・保全を 行っている。例えば、草花の採取に対する監視や魚を採ることに対して罰金が課せられる。

・植生、生物等の生態系の実態を人々に理解してもらう

環境教育の実践や観光客を受け入れ、自然の観察や直接触れる機会を創り、自然の貴重性を広く理解させる。 ・科学的な観察の場を提供する

様々な分野の研究者に、ありのままの自然を実験フィールドとした研究活動の場を設けることにより、自然の貴 重性のより深い理解を得る。

・公園内の住民の生活にも寄与する。

緊急時の対応や、日常の生活援助を行う。

\section{(2) 国立公園の自然保蒦管理区域区分}

国立公園内は通常次の 3 つの地域に区分（ソーニング） されて、自然環境の保全・管理がなされているが、2つ の区域 ( $\mathrm{a}$ 及びb) だけの場合もある。

a. 住民と自然が共存する区域 (habi tee)

b. 中心ソーン (Zone centrak): 人は住んでいない が立ち入りは可能な区域

c. 完全保存区域：貴重種があり研究者や管理者だ けしか入れない区域。

(3) 国立公園内の開発行為について

公園内の開発行為は禁止されており、家屋等の改築に も許可が必要である。詳細な規定を課されて許可された 例外はあるが、基本的に開発行為は出来ない。市町村に よる港湾建設も同様である。

また、ポルクロール島及びラーデ行岬地域においても 様々な保全措置が実施されており、ポルクロール島では マッシュルームの採取、狩猟及び交通手段等が法律で規 制されている。ラーディア岬は沿岸域保全機関が保有し ており、自動車の乗り入れ等が一切禁止されている。

(4) ポールクロー公園の貢献事項

ポールクロー公園は、国立公園の使命（Mission）に 基づき以下のような役割を果たしている。

・自然保護に関する成功例の展開あるいは失敗例による

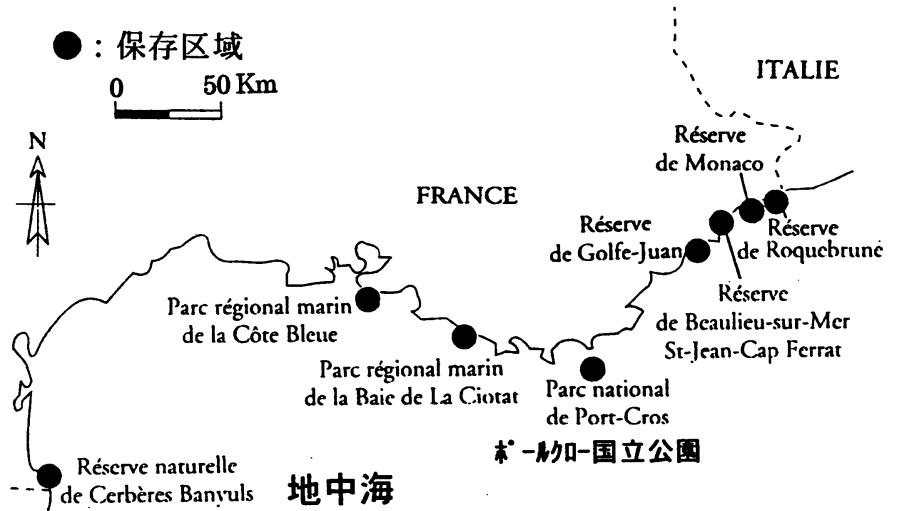

図一1地中海沿岸域の保存区域 ${ }^{81}$

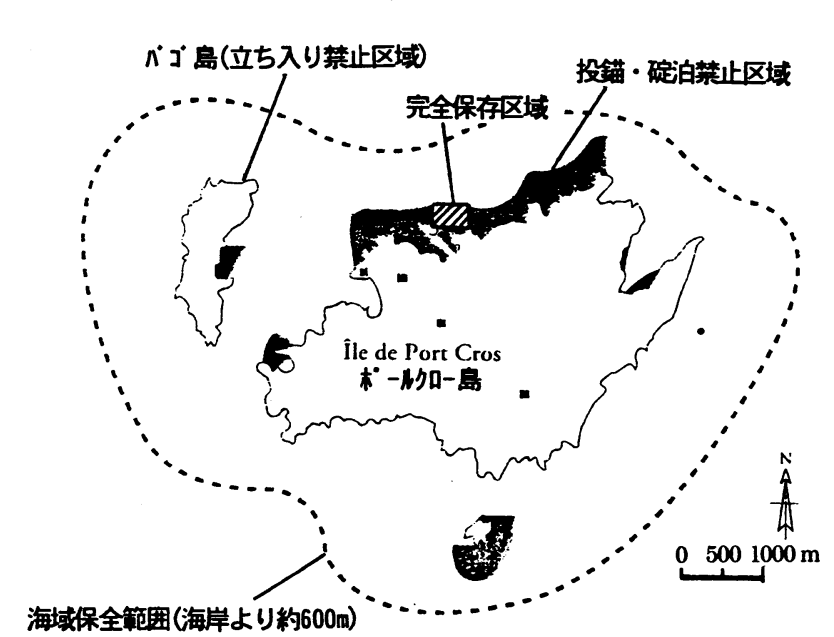

図－5 ポールクロー国立公園と自然保護区分 ${ }^{81}$ 
警告

地中海生物のありのままの自然を対偊とし た実験の場として、研究活動により得られた 技術的・生態管理の成功事例を他に展開した り、あるいは失敗例から問題点を探る。

・自然の貴重性を啓蒙する

特徵をもった空間をメディアを通して訴え ること等により自然の貴重性を啓蒙する。

・貴重種の維持とプロダクション

地中海における貴重植物の種を保存 (Porquerolles島の植物園)し、ある地域の生態が 火災等で消失した場合にも備えている。

・島に住む住民の生活援助を行う

観光化による経済的側面での援助や、日常 の薪の運び出し等を手伝う。

\section{(5) 自然保菣管理区域の区分}

先に示した $3 つ$ つ地域に区分した管理が行われており、バゴ島 (40ha) は全域が立ち入り禁止の保存区域に指定さ れている。海域の保護籁囲は、保護すべき生態系の生息域や地形を考慮して決められており、ポールクロー島の場 合は、海藻 (Poseidonie等) 生息域が沖合約 $300 \mathrm{~m}$ であることから (これより外は砂)、その範囲に余裕を持たせてお よそ $600 \mathrm{~m}$ 設定している。これらの区域では、水中ハンティングや水中植物の移設等が禁止されている。また、そ の一部では投鈚を禁止する区域設定がなされている。設定笧囲については 5 年毎に見直しと改訂が行われている。

\section{4 漁業資源に対する保全}

図ー4に示した保全区域の設定では、漁業資源の保全を主目的としたモナコ などの保存区域の例もある。また、ラングドック州の地中海海岸線にある夕 ホ湖などの潟・内海では、牡蝴やムール貝の養殖が盛んに行われている。牡 蜼の年間生産量は約 $35,000 \mathrm{t}$ あ、内海周辺地域の重要な収入源になっている。 しかし、その一方で生活雑排水、工場排水及び養殖による自己污染などで内 海の污染が進み、富栄養化が深刻化している。また、近年の工業化の進展に 伴う水質污染も深刻であるが、これらに対するミティゲーション的な措置は 取られていない。污染対策としては、牡螅やムール貝への影響に配慮して、 化学的処理を行わないバイオロジカルな処理システムにより生活雑排水の処 理が行われ一定の成果をあげている。このような施設は、環境教育の一睘と して課外授業等の場としても利用されている。また工場排水に対しては、企 業から環境影響調査や水質浄化に関して大学等に研究を委託するなどの対応 が進められており、企業責任をこのような形で果たしている状況もある。

\section{3. 地中海型ミティゲーションと日本への適応性}

3. 1 基本的考え方

フランスの開発に対する基本的な考え方は、開発効果による受益を考慮しつ つ環境との均衡点を探る方法である。ミティゲーション的施策としては、メ ネーズらによる主に海域を対象とした地中海型ミティゲーションの概念が現 実的な方法として検討されている。この考え方は、一度失われた生物環境は 容易に元の状態に戻らないため、開発地で最小化を図るとともに修復措置と して開発地域の近くに一切手を加えることのない生態系の「保存区域」を設 圆することを基本に考える方法である。ある圈域内でこの考え方を適用した ケースを概念的に示せば、図ー 6 の A と B 関係で表される。このような考 え方は、メネーズらが示しているように、開発サイドにとってリスクの少な い方法であり、我が国への適用も有效と考えられる。一方、地中海型ミティ ゲーションでは圈域の生態環境の全体的な量や質の増強については言及して

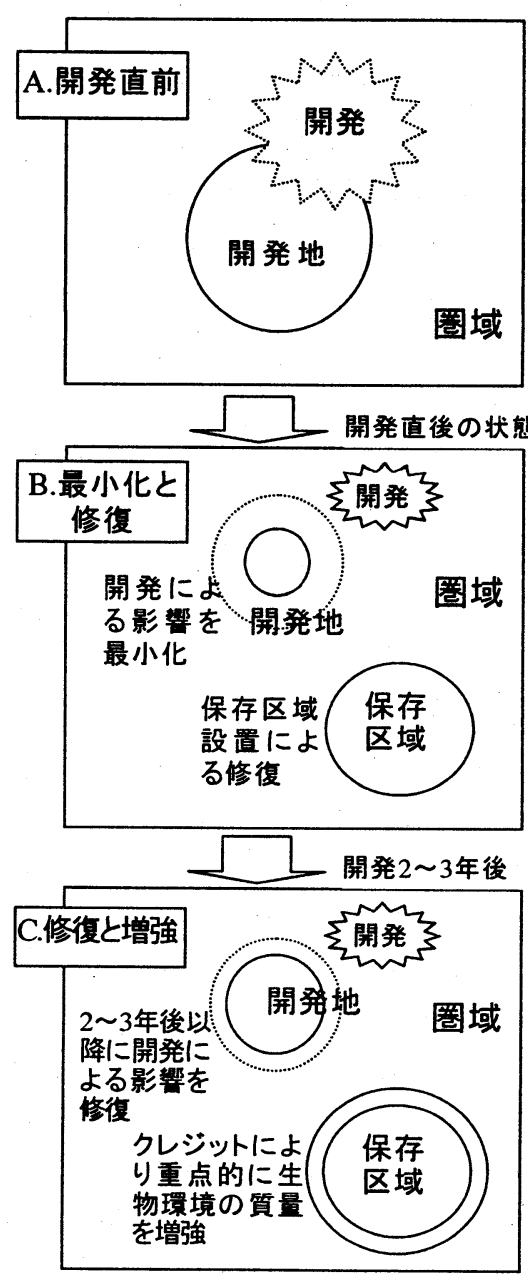

図-6 開発に伴う環境への影響と ミティゲーションの考え方
: 生物環境の質と量の大きさを示す 
いない。むしろ、ミティゲーション比率は 1 以下でも可とする考え方をとっている。

この点を考虑して、地中海型ミティゲーションの我が国への適用を考えれば、最小化と修復による方法に加えて設 狊した保存区域の生物環境の質や量の増強を図る方法が適切であり、その基本的な考え方を次に示す。ここではこの ような考え方を日本型ミティゲーションと定義する。また、その概念を図ー6のCに示す。

(1) 失われた生物環境は短時間では元の状態には戻らないことを考慮する。

(2) 圈域内における生物環境の質と量の維持增強を図る。

(3) 保存区域の重点的な生物環境の增強措置を図る。

(4) 開発地への影響は出来る限り最小化する。

(5) 開発地も目標值を設定し、修復指置を講ずる。

このとき修復や增強の費用は、開発の環境への影響度合いを考慮して拠出する保存基金を充当することや、そのク レジット化で得られた費用を充てる方法が現実的である。また、開発地における開発直後の生物環境は不安定であり、 開発地の修復を実施する場合には、ある程度生物環境が安定した後に実施する方法が有効と考えられ、ここでは開発 から修復措置に至る事業の継続性も考慮して、その期間を $2 \sim 3$ 年と想定した。

\section{2 日本型ミティゲーションのフロー}

日本型ミティゲーションのフローを図ー 7 に示す。開発に当たっては予め開発地と同一圈域内に保存区域を設定 しておく必要がある。保存区域としては、国立公園など豊かな自然を有する区域、笧囲の限定が容易な島、あるいは 松枯れ等が著しく環境バランスの崩れつつある地域などが考えられる。また同時に、事業費の一部からの拠出等に基 づく保存基金制度や、その基金を適用して対象保存区域の生物睘境の増強を図るシステムの確立が必要である。この 保存基金はクレジット化によりバンキング機能を持たせることも可能となり、その方法によればより高い実効性が期 待できる。

開発の事業化に当たっては、図に示すように 先ず回避の可能性を検討する。回避不可能の場 合には、事業化することとなるが、このとき生 物環境に与える影響を最小化する方法を考える。 更に、最小化後の生物環境への影響の程度を評 洒して、その程度に応じたクレジット額を定め、 保存基金への拠出やクレジットの購入を条件に 開発事業が許可される。開発事業の実施後は、 開発地生物環境の安定する $2 \sim 3$ 年後以降に、 開発地域を対象とした修復措置を実施する。こ れらの修復措置と保存区域の生物環境の增強に よる圈域内環境状態の目標值は、開発前の状態 よりも高くすることが望まれる。この状況を示 せば図ー8 となる。即ち、開発地における当初 の環境状態は、その直後は開発行為によって低 下する。しかし、修復措置を講ずることにより 元の状態への回復が図られる。一方、保存区域 では生物環境の增強措置を採ることにより、睘 境状態は向上する。これらの効果を足し合わせ れば、開発後の圈域内の環境状態は、一定期間 経過後には現状より良好になっている。

\section{3 適用に当たっての課題}

日本型ミティゲーションの実施に当たっては、 圈域内の生物睘境量や質の維持向上を目標とす るため、予め圈域の設定が必要になる。圈域と しては同一海域や貴重種等の生息篹囲を基準と するなど様々な形態が考えられるが、具体的な 籁冊設定方法については今後の課題である。

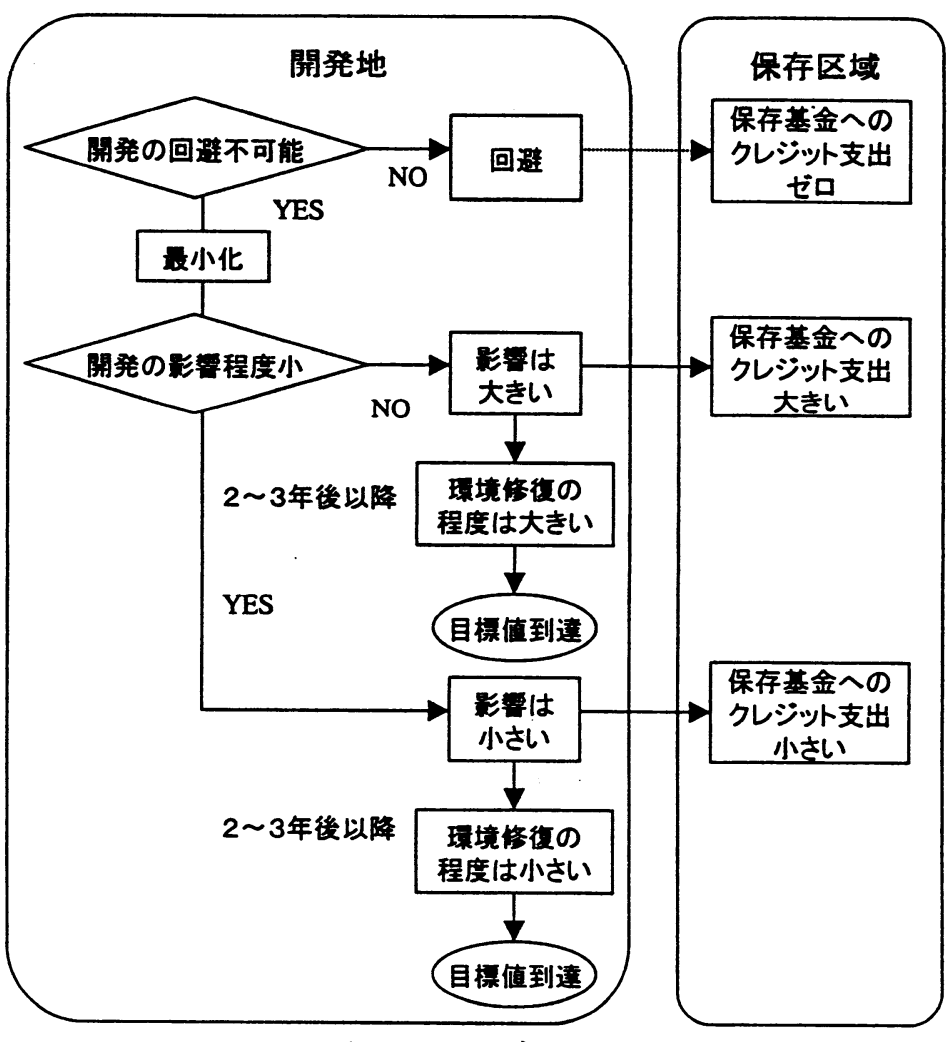

図ー7 日本型ミティゲーションのフロー
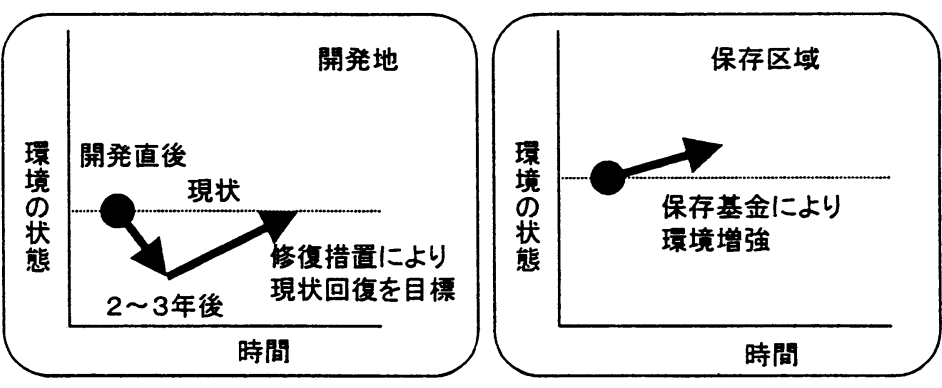

図ー8 日本型ミティゲーションによる睘境状態の推移 
また、開発影響の程度や、その評洒に対する保存基金へのクレジットの大きさを決める必要もある。開発が及ぼ す環境への影響の評価は、既に法制化された睘境影響評価の結果を利用する方法も考えられるが、対象から外れる事 業についての取り扱い等の問題もある。保存基金へのクレジットの大きさは、開発費用の一部ともなるものであり適 正な費用をどのように設定するかは大きな課題である。これらに関しては、実績のある米国の事例を参考にすること や、既に多く報告されている評価方法の実用的展開により、より一層の汎用化を進めることが必要と考えられる91。

\section{4. 結論}

地中海沿岸域におけるミティゲーションの実態調査を行い以下のことが分かった。

・フランスではミティゲーションの法制化に至っていない。むしろ観光化などの開発受益を重視する姿勢が強い。 しかし、沿岸域法や景観法等の法制化により環境破壊に対する一定の抑止は図られている。

・ミティゲーション的施策（地中海型ミティゲーション）としては、開発インパクトに対する影響の最小化と修復 措置をともに実施する方法が検討されている。この考元方の基本にあるのは、代償措置等で開発インパクトを完 全に補うことは困難であるという観点に立ったものである。また修復方法としては、開発地に近い区域に開発行 為の及ばない保存区域を設置し、その修復を中心とする方法が持続可能で現実的であるとしている。

・保存区域の例として、国立公園内の自然保護管理区域などがあるが、現状ではミティゲーション的施策との直接 的な関連措置はとられていない。

また、地中海型ミティゲーションの考え方は日本への適用性があり、この概念をより進めた日本型ミティゲーショ ンでは高い鱑境保全が期待でき、以下のような点で有効である。

・保存区域の設置とその地域の生物環境の質や量を增強させる考え方は、低リスクで高い効果が期待できる。

・圈域内の生物環境の質や量の維持向上を目標としたとき、開発地における最小化と修復措置の実施及び保存区域 の設定を組み合わせる方法が有效であり、効果も期待できる。

・保存基金へのクレジット化では、開発の影響に応じた基金設定ができ、保存区域における生物睘境增強の資金的 背景となり得る。

\section{5. あとがき}

日本海洋建設協会ミティゲーション技術専門委員会による欧州ミティゲーション調査では、オランダ、ドイツ及び フランスの 3 力国を調査した。これら欧州各国では、多くの国と国境を接し自国の環境悪化がそのまま他国への影響 につながるためか環境保全意識が高く、海域や河川など共有の資源では特にその意識は高いようである。そのため、 将来を担う世代に対する襄境教育が多く実施されている。我が国においては、島国であるためかこれらの共有資源と しての意識は薄いようであり、今後今以上に睘境教育の充実が望まれる。保存基金の一部は、このような将来世代に 環境の重要性を認識させるための環境教育にも反映し、開発一睘境一教育の輪を形成することは、持続的成長可能な 社会形成に寄与する一方法であると思われる。

\section{謝 辞}

本論文は、(社) 日本海洋建設協会のミティゲーション技術専門委員会による欧米のミティゲーション調查結果の 一部を取りまとめたものである。国内外の調査に当たっては、関連諸機関の多大な助力の下に貴重な資料を収集する 事ができた。現地調查では、ニース大学メネーズ教授を初めとする多くの方から、丁寧な現状紹介や関連資料を頂く ことが出来た。また、関係各位には論文作成に当たって貴重なご意見を頂いた。ここに深く感謝する。

\section{参考文献）}

1）中原裕幸: ミティゲーション、海岸、Vol. 33, No. 1, 1993など.

2）（財）日本建設情報総合センター：特集・ミティゲーション、JACIC情報、Vol. 9, No. 3, 1994, pp5-14.

3）港湾環境創造研究会：よみがえる海辺、山海堂、1997.

4）磯部雅彦：米国におけるミティゲーションの動向、沿岸域、第10巻、第 1 号、1997.

5）金芳晴：「社会システム上の諸問題…漁業権及び沿岸開発」、ミチゲーションセミナー資料、（財）日本システ 厶開発研究所、1993.

6）（社）日本海洋開発建設協会：米国および欧州のミチゲーション技術に関する調查報告書、1998.

7）（財）日本生態系協会：ドイツの水法と自然保護、1996.

8) J. P. Cesson, A. Meinesz et al. : Mer Vivante, Lions Club Nice-Doyen, 1997, pp38-53.

9）阪東浩造他：開発地域の環境価值評価方法について、海洋開発論文集、Vol. 13, 1997, pp225-230. 